Sains Malaysiana 50(1)(2021): 171-179

http://dx.doi.org/10.17576/jsm-2021-5001-17

\title{
Quantified Piper sarmentosum Roxb. Leaves Aqueous Leaf Extract and Its Antihypertensive Effect in Dexamethasone-Induced Hypertensive Rats
}

(Kuantifikasi Daun Piper sarmentosum Roxb. Ekstrak Daun Akueus dan Kesan Antihipertensi pada Tikus Hipertensi Aruhan Deksametason)

\author{
Muhammad Firdaus Azmi, Amilia Aminuddin, Jamia Azdina Jamal, Adila A Hamid \& Azizah Ugusman*
}

\section{ABSTRACT}

The quality control of raw herbal materials is important to ensure the safety, efficacy, and reproducibility of herbal products. Herbal products with consistent efficacy should be standardized and quantified based on their bioactive phytochemical compounds. Piper sarmentosum Roxb. has been reported for its antihypertensive activity. However, its antihypertensive effect on dexamethasone-induced hypertension still lacks information. In this study, the quality of two batches of raw P. sarmentosum leaf materials was assessed for heavy metal and microbial contents, and their aqueous extracts were assayed for antioxidant activity. The aqueous extract of the second batch of $\mathrm{P}$. sarmentosum leaves was the only extract that passed the heavy metal and microbial limits and had the highest antioxidant activity $(50.00 \pm 2.88 \%)$; therefore, this extract was used for subsequent studies. The extract was quantified for two phytochemical markers, rutin (0.09 $\pm 0.002 \%)$ and vitexin $(0.23 \pm 0.007 \%)$, using a validated ultrahigh performance liquid chromatography method. The quantified extract (500 $\mathrm{mg} / \mathrm{kg} /$ day orally) was able to lower the systolic blood pressure, diastolic blood pressure, and mean arterial pressure of dexamethasone-induced hypertensive rats comparable to the positive control drug, captopril. In summary, the quantified aqueous extract of P. sarmentosum based on rutin and vitexin lowers the blood pressure of dexamethasone-induced hypertensive rats, but its underlying mechanism warrants further investigation.

Keywords: Dexamethasone; hypertension; Piper sarmentosum; quantified extract; ultrahigh performance liquid chromatography

\section{ABSTRAK}

Kawalan kualiti ke atas bahan mentah herba adalah penting untuk memastikan keselamatan, keberkesanan dan kebolehkeluaran produk herba tersebut. Produk herba yang mempunyai keberkesanan yang tekal perlu dipiawai dan dikuantifikasi berdasarkan sebatian fitokimia bioaktif masing-masing. Piper sarmentosum Roxb. dilaporkan mempunyai aktiviti antihipertensi. Namun begitu, masih terdapat kekurangan maklumat berkenaan kesannya terhadap hipertensi aruhan deksametason. Dalam kajian ini, kualiti dua kumpulan bahan mentah daun P. sarmentosum diukur kandungan logam berat dan mikrobnya dan ekstrak akueusnya diuji untuk aktiviti antioksidan. Hanya ekstrak akueus daripada kumpulan kedua daun P. sarmentosum menepati had kandungan logam berat dan mikrob serta mempunyai aktiviti antioksidan tertinggi (50.00 $\pm 2.88 \%)$; oleh itu ekstrak ini digunakan untuk kajian berikutnya. Ekstrak tersebut dikuantifikasi dengan dua penanda fitokimia, rutin (0.09 $\pm 0.002 \%)$ dan viteksin (0.23 $\pm 0.007 \%)$, menggunakan kaedah kromatografi cecair berprestasi ultratinggi yang telah disahkan. Rawatan dengan ekstrak yang telah dikuantifikasi $(500 \mathrm{mg} / \mathrm{kg} /$ hari secara oral) dapat mengurangkan tekanan darah sistolik, tekanan darah diastolik dan tekanan arteri purata tikus hipertensi aruhan deksametason setanding dengan ubat kawalan positif, captopril. Kesimpulannya, ekstrak akueus P. sarmentosum yang dikuantifikasi berdasarkan rutin dan viteksin berjaya merendahkan tekanan darah tikus hipertensi aruhan deksametason tetapi mekanisme dasarnya perlu dikaji dengan lebih lanjut lagi.

Kata kunci: Deksametason; ekstrak dikuantifikasi; hipertensi; kromatografi cecair berprestasi ultratinggi; Piper sarmentosum 


\section{INTRODUCTION}

The usage of herbal products as complementary treatment for various health problems such as hypertension and diabetes mellitus, has been expanding worldwide (WHO 2013). Although some herbal products have promising potential for health, their efficacy may not be consistently reliable if their quality is not controlled. Quality control is a process that maintains the reproducibility of batch-tobatch production to ensure the quality, safety, and efficacy of herbal products (Kumari \& Kotecha 2016), because the quality of herbal materials can be altered upon harvesting, storing, and processing.

Quality control testing is an essential component of the herbal standardization process. The quality control of herbal materials involves the assessment of authenticity; quality; limit of contaminants, such as heavy metals and microbes; and chemical marker(s). In general, one or two phytochemical markers or pharmacologically active components in herbs are employed to evaluate the quality of herbal products. Chromatographic techniques, such as high performance liquid chromatography (HPLC), ultrahigh performance liquid chromatography (UPLC), and gas chromatography, can be applied for the quantification of chemical markers as part of the quality control assessment of herbal materials (Kumari \& Kotecha 2016). Piper sarmentosum Roxb. is an herbaceous plant that is commonly found in Southeast Asia. Traditionally, $P$. sarmentosum leaves have been used to treat cough, flu, and rheumatism (Seyyedan et al. 2013). Pharmacologically, the aqueous extract of $P$. sarmentosum leaves has antihypertensive (Zainudin et al. 2015), antioxidant (Hussain et al. 2009), and antihypercholesterolemic actions (Amran et al. 2010).

Hussain et al. (2009) standardized the ethanol and aqueous extracts of various parts of $P$. sarmentosum based on piperine, rutin, and flavonone using HPLC. In another study, pellitorine, sarmentine, and sarmentosine were used to standardize the ethanol extract of $P$. sarmentosum fruits and leaves (Hussain et al. 2010). Other phytochemical compounds reported in previous studies are rutin and vitexin (Ugusman et al. 2012) and piperflaviflorine A and B and sarmentamide D (Shi et al. 2017).

The present study focused on the quality control involved in producing the quantified aqueous extract of $P$. sarmentosum leaves based on two flavonoid compounds, rutin and vitexin, as chemical markers using a validated UPLC method. Rutin and vitexin were selected as they are the major flavonoids found in the aqueous extract of $P$. sarmentosum leaves (Ugusman et al. 2012). Subsequently, the effect of the quantified extract on the blood pressure of dexamethasone-induced hypertensive rats was evaluated.
Dexamethasone is a glucocorticoid with potent and long-lasting effects. One of the side effects of prolonged dexamethasone intake is secondary hypertension (Albrecht et al. 2015). Dexamethasone causes hypertension via several stipulated mechanisms, such as increased oxidative stress (Liu et al. 2018), the overactivation of the renin-angiotensin-aldosterone system (Xiao et al. 2018), and nitric oxide (NO) reduction (Huyut et al. 2018).

\section{MATERIALS AND METHODS}

CHEMICALS

Rutin, vitexin, 2,2-diphenyl-1-picrylhydrazyl (DPPH), and ascorbic acid were purchased from Sigma Aldrich, USA. Dexamethasone and captopril were purchased from Cayman Chemical, USA. UPLC-grade methanol, acetonitrile, and formic acid were obtained from Merck, USA.

\section{PLANT COLLECTION AND PREPARATION}

The first batch of $P$. sarmentosum leaves (PS1) was supplied by Ethnoresources Sdn. Bhd., Sungai Buloh, Malaysia, and the second batch of $P$. sarmentosum leaves (PS2) was supplied by Herbagus Sdn. Bhd., Kepala Batas, Malaysia. A voucher specimen was deposited at the Herbarium of Universiti Kebangsaan Malaysia with reference number UKMB40240. Both batches of leaves were washed, oven-dried at $80{ }^{\circ} \mathrm{C}$ for $12 \mathrm{~h}$, ground to powder, and sieved using a $5 \mathrm{~mm}$ mesh.

\section{DETERMINATION OF HEAVY METAL CONTENT FOR QUALITY CONTROL}

Heavy metal determination tests were carried out on the powdered leaves based on the BS EN 14084:2003 method (British Pharmacopeia 2018) to determine the amount of heavy metals, such as arsenic, mercury, cadmium, and lead.

\section{DETERMINATION OF MICROBIAL CONTENT FOR QUALITY CONTROL}

The method described in the Appendix XVI B of British Pharmacopeia (2018) was used for the microbial tests to determine the Escherichia coli, Staphylococcus aureus, and aerobic microorganism contents of the powdered leaves.

\section{EXTRACTION OF P. sarmentosum LEAVES}

Extraction was done as described previously (Ugusman et al. 2012). Powdered PS1 and PS2 were extracted separately using a high-speed extractor machine. Ten liters of distilled water was mixed with each kilogram of 
dried leaves (ratio $1: 10, \mathrm{v} / \mathrm{v}$ ), and the mixture was heated at $80^{\circ} \mathrm{C}$ for $3 \mathrm{~h}$. Steel filter in the extractor machine was used to filter the dried leaves from the crude extract. The filtered crude extract was concentrated by boiling and freeze-drying. Two sets of aqueous extracts, namely, the aqueous extracts of PS1 (AEPS1) and PS2 (AEPS2), were obtained and stored at $4{ }^{\circ} \mathrm{C}$ until further use.

\section{ANTIOXIDANT ASSAY}

The in vitro antioxidant activities of AEPS1 and AEPS2 were tested using DPPH radical scavenging assay. Ascorbic acid was used as positive control. All samples were tested in triplicates. A total of $100 \mu \mathrm{L}$ of AEPS1, AEPS2, and ascorbic acid $(300 \mu \mathrm{g} / \mathrm{mL})$ were added into a 96-well plate. Then, $100 \mu \mathrm{L}$ of DPPH solution $(500 \mu \mathrm{M})$ was added into the wells and left for $30 \mathrm{~min}$ in the dark. Subsequently, the absorbance values of the samples were measured at the wavelength of $517 \mathrm{~nm}$. Free radical scavenging activity was calculated based on the following formula:

$$
\text { Scavenging effect }(\%)=\left[1-\left(\frac{A-B}{C}\right)\right] \text {, }
$$

where $A, B$, and $C$ are the absorbance values of the sample with DPPH, the blank sample, and DPPH, respectively.

\section{UPLC}

Analysis was performed on AEPS2 using an UPLC system equipped with degasser, quarternary pump, autosampler, and photodiode array detector (Waters Acquity ${ }^{\circledR}$, UK) based on the data obtained from the determination of heavy metal and microbial contents and the antioxidant assay. The extract and standards were analyzed through a validated method using a reversed-phase C18 column (Waters Symmetry ${ }^{\circledR}, 5 \mu \mathrm{m}, 3.9 \times 150 \mathrm{~mm}^{2}$ ) and two gradient mobile phases comprising two reagents: $0.1 \%$ formic acid in water (reagent A) and $0.1 \%$ formic acid in acetonitrile (reagent B). Initial conditions were $85 \%$ reagent $\mathrm{A}$ and $15 \%$ reagent $\mathrm{B}$ with linear progression reaching $75 \%$ reagent $\mathrm{A}$ and $25 \%$ reagent $\mathrm{B}$ at $\mathrm{t}=8 \mathrm{~min}$. This condition continued until $\mathrm{t}=14$ minute at a flow rate of $0.4 \mathrm{~mL} / \mathrm{min}$. Detection was carried out at the wavelength of $366 \mathrm{~nm}$ and injection volume of $10 \mu \mathrm{L}$. AEPS $2(50 \mathrm{mg} / \mathrm{mL})$, standards (rutin and vitexin at $0.025,0.05,0.1,0.2,0.4 \mathrm{mg} / \mathrm{mL}$ ), and AEPS2 spiked with rutin and vitexin $(0.1 \mathrm{mg} / \mathrm{mL})$ were analyzed in triplicates. Method validation was performed based on the standard curves of rutin and vitexin from inter- and intra-day analyses. Intra-day analysis was done by analyzing five different concentrations $(0.025,0.05$, $0.1,0.2$, and $0.4 \mathrm{mg} / \mathrm{mL}$ ) of vitexin and rutin in triplicates. Inter-day analysis was completed by analyzing similar concentrations of vitexin and rutin for three consecutive days. Other parameters for method validation were accuracy, linearity range, limit of detection, and limit of quantitation (ICH 2005).

\section{ANIMAL STUDY PROTOCOL}

The study protocol was approved by the Animal Ethics Committee of Universiti Kebangsaan Malaysia (Reference number: PP/FISIO/2015/ZAITON/20-MAY/678MAY-2015-DEC-2016). Thirty male Sprague Dawley rats aged 8-12 weeks and weighing 250-300 g were obtained from the animal house of Universiti Kebangsaan Malaysia, Kuala Lumpur. The rats were acclimatized for 7 days in standard cages at the animal house of the Faculty of Science and Technology, Universiti Kebangsaan Malaysia. Tap water and standard food pellets were given ad libitum. Animals were randomly grouped into five groups $(n=6)$ and labelled as group 1 (control), group 2 (treated with 500 $\mathrm{mg} / \mathrm{kg}$ /day AEPS2 via oral gavage [p.o.]), group 3 (treated with $20 \mu \mathrm{g} / \mathrm{kg} /$ day dexamethasone via subcutaneous injection [s.c.]), group 4 (treated with $20 \mu \mathrm{g} / \mathrm{kg} / \mathrm{day}$ dexamethasone s.c. and $500 \mathrm{mg} / \mathrm{kg} /$ day AEPS 2 p.o.), and group 5 (treated with $20 \mu \mathrm{g} / \mathrm{kg} /$ day dexamethasone s.c and $40 \mathrm{mg} / \mathrm{kg} /$ day captopril p.o.). The dosage of dexamethasone used was based on a previous research (Ong et al. 2009). The dosage of AEPS2 proven to attenuate hypertension in spontaneously hypertensive rats (SHRs) (Zainudin et al. 2015) and L-N $\mathrm{N}^{\mathrm{G}}$-nitro arginine methyl ester (L-NAME)-induced hypertensive rats (Nik Mohd Alwi et al. 2018) was selected. SHR is the gold standard animal model for studying hypertension (Trindade et al. 2018), whereas L-NAME is widely used to create a NO-deficient hypertension model (Vrankova et al. 2019). One of the mechanisms of dexamethasone-induced hypertension is through NO reduction (Huyut et al. 2018); thus, we chose our AEPS dose based on the aforementioned studies.

\section{BLOOD PRESSURE MEASUREMENT}

The blood pressure (systolic blood pressure [SBP], diastolic blood pressure [DBP], and mean arterial pressure [MAP]) of conscious rats was measured at days 0,14 and 28 using a non-invasive tail cuff method (CODA ${ }^{\mathrm{TM}}$, Connecticut, USA). Five readings were recorded during each measurement. The highest and lowest readings were removed, and the average of the remaining three readings was taken as the final value (Nik Mohd Alwi et al. 2018).

\section{STATISTICAL ANALYSIS}

DPPH and UPLC assay results were analyzed using Microsoft Office Excel 2010 and Curve Expert 1.4, and blood pressure results were analyzed using SPSS software version 20. Data were tested for normality using Shapiro-Wilk test, and results showed that all variables 
were normally distributed. Data were presented as mean \pm standard error of mean. One-way ANOVA followed by post-hoc Tukey test was performed to analyze the difference between groups. The difference was considered significant at $P<0.05$.

\section{RESULTS}

\section{DETERMINATION OF HEAVY METAL AND MICROBIAL} CONTENTS OF DRIED P. sarmentosum LEAVES

Table 1 shows the heavy metal contents of dried PS1 and PS2. PS1 and PS2 contained traces of arsenic, lead, cadmium, and mercury that did not exceed the specified limit. Table 2 shows the microbial contents of PS1 and PS2. The total counts of viable aerobic bacteria and fungi in PS1 were above the limit, whereas none of the microbial contaminants in PS2 exceeded the specified limit.

\section{ANTIOXIDANT ACTIVITY OF P. sarmentosum AQUEOUS EXTRACTS}

Table 3 shows the antioxidant activities of AEPS 1 and AEPS2 $(300 \mu \mathrm{g} / \mathrm{mL})$ based on the DPPH radical scavenging test compared with the antioxidant activity of the positive control, ascorbic acid $(300 \mu \mathrm{g} / \mathrm{mL})$. The antioxidant activity of AEPS 2 reached $50 \%$. Only AEPS2 was used for subsequent UPLC analysis and in vivo study because of its antioxidant activity, and its dried leaves did not contain heavy metal and microbial contamination that exceed the safety limit.

\section{UPLC ANALYSIS}

Table 4 shows the summary of the UPLC validation data for the linear calibration curves of rutin and vitexin. Figure 1 shows the chromatograms of rutin (Figure 1(A)), vitexin (Figure 1(B)), and AEPS2 (Figure 1(C)). The retention times for rutin and vitexin standards were 9.045 and $9.410 \mathrm{~min}$, respectively. The retention times for rutin and vitexin detected in AEPS2 were 9.082 and $9.485 \mathrm{~min}$, respectively. AEPS2 was spiked with rutin and vitexin, and the chromatogram further confirmed the presence of rutin (Figure 1(D)) and vitexin (Figure 1(E)) in AEPS2. Quantitative analyses of rutin and vitexin in AEPS2 were done based on the rutin calibration curve $(y=19761 \mathrm{x}+$ $\left.116267, \mathrm{r}^{2}=0.9998\right)$ and vitexin calibration curve $(\mathrm{y}=$ $\left.10313 \mathrm{x}+53547, \mathrm{r}^{2}=0.9997\right)$. The concentration of rutin in AEPS2 was $0.0424 \pm 0.001 \mathrm{mg} / \mathrm{mL}(0.09 \% \pm 0.002 \%)$, and that of vitexin was $0.1163 \pm 0.003 \mathrm{mg} / \mathrm{mL}(0.23 \% \pm$ $0.007 \%)$

\section{EFFECTS OF AEPS2 ON THE BLOOD PRESSURE OF DEXAMETHASONE-INDUCED HYPERTENSIVE RATS}

Table 5 shows the blood pressure readings at baseline (day 0 ) and at days 14 and 28 post-treatment. At baseline, no remarkable difference was observed among the groups in all the blood pressure parameters, namely, SBP, DBP, and MAP. Rats treated with AEPS2 did not show any substantial change in blood pressure compared with control throughout the study.

Induction with dexamethasone significantly increased SBP $(P<0.001$ at days 14 and 28$)$, DBP $(P<0.05$ at day 14 and $P<0.001$ at day 28$)$, and MAP $(P<0.05$ at day 14 and $P<0.001$ at day 28) compared with the control group. The supplementation of AEPS to the hypertensive rats significantly lowered the rats' SBP $(P<0.001$ at days 14 and 28), DBP $(P<0.05$ at day 14 and $P<0.001$ at day 28), and MAP $(P<0.05$ at day 14 and $P<0.001$ at day 28) compared with the rats in the dexamethasone group. These antihypertensive effects were comparable with the effects of captopril.

TABLE 1 . Heavy metal content of dried P. sarmentosum leaves compared to the national limit

\begin{tabular}{lcccl}
\hline & \multicolumn{2}{l}{ Heavy metal content $(\mathrm{ppm})$} & & Limit of heavy metal content (ppm) (NPRA 2016) \\
\cline { 2 - 3 } Heavy metal & PS1 & PS2 & & Not more than 5.0 \\
\cline { 2 - 3 } Arsenic & 0.15 & 0.44 & Not more than 0.3 \\
Cadmium & 0.20 & 0.07 & Not more than 0.5 \\
Mercury & 0.05 & 0.01 & Not more than 10 \\
Lead & 3.68 & 1.79 &
\end{tabular}

PS1: First batch of $P$. sarmentosum dried leaves; PS2: Second batch of $P$. sarmentosum dried leaves; ppm: part per million; NPRA: National Pharmaceutical Regulatory Agency 
TABLE 2. Microbial content of dried P. sarmentosum leaves compared to the national limit

\begin{tabular}{|c|c|c|c|}
\hline \multirow[t]{2}{*}{ Microorganism } & \multicolumn{2}{|c|}{ Microbial content } & \multirow{2}{*}{$\begin{array}{l}\text { Limit of microbial content } \\
\text { (NPRA 2016) }\end{array}$} \\
\hline & PS1 & PS2 & \\
\hline $\begin{array}{l}\text { Total count of viable } \\
\text { aerobic (bacteria) }\end{array}$ & $2.3 \times 10^{7} \mathrm{cfu} / \mathrm{g} *$ & $5.0 \times 10^{4} \mathrm{cfu} / \mathrm{g}$ & $\leq 1 \times 10^{7} \mathrm{cfu} / \mathrm{g}$ \\
\hline $\begin{array}{l}\text { Total count of viable } \\
\text { aerobic (fungi) }\end{array}$ & $3.0 \times 10^{6} \mathrm{cfu} / \mathrm{g} *$ & $3.0 \times 10^{2} \mathrm{cfu} / \mathrm{g}$ & $\leq 1 \times 10^{4} \mathrm{cfu} / \mathrm{g}$ \\
\hline Escherichia coli & $<2.0 \times 10^{1} \mathrm{cfu} / \mathrm{g}$ & $<2.0 \times 10^{1} \mathrm{cfu} / \mathrm{g}$ & $<1.0 \times 10^{2} \mathrm{cfu} / \mathrm{g}$ \\
\hline Salmonella spp. & Absent in every $10 \mathrm{~g}$ & Absent in every $10 \mathrm{~g}$ & Absent in every $10 \mathrm{~g}$ \\
\hline Staphylococcus aureus & Absent in every $1 \mathrm{~g}$ & Absent in every $1 \mathrm{~g}$ & Absent in every $1 \mathrm{~g}$ \\
\hline
\end{tabular}

PS1: First batch of P. sarmentosum dried leaves; PS2: Second batch of P. sarmentosum dried leaves; g: gram; cfu/g: colony-forming unit per gram; spp: species; NPRA: National Pharmaceutical Regulatory Agency. *: exceeding the specified limit

TABLE 3. Antioxidant activity of $P$. sarmentosum aqueous extracts

\begin{tabular}{cc}
\hline Sample & Antioxidant activity (\%) \\
\hline AEPS1 & $21.77 \pm 2.27$ \\
AEPS2 & $50.00 \pm 2.88$ \\
Ascorbic asid & $93.10 \pm 4.21$ \\
\hline
\end{tabular}

AEPS1: aqueous extract of PS1; AEPS2: aqueous extract of PS2

TABLE 4. UPLC assay validation from inter- and intraday analysis for rutin and vitexin standards

\begin{tabular}{lcc}
\hline Assay validation & Rutin & Vitexin \\
\hline Accuracy (\%) & $97.84 \pm 2.46$ & $97.70 \pm 2.86$ \\
Slope & 19761 & 10314 \\
Intercept & 116267 & 66464 \\
Linearity range (part per million) & $25-400$ & $25-400$ \\
Inter-day correlation coefficient $\left(\mathrm{r}^{2}\right)$ & 0.9998 & 0.9997 \\
Intra-day correlation coefficient $\left(\mathrm{r}^{2}\right)$ & 0.9996 & 0.9990 \\
Standard error of intercept & 31390.42 & 20179.5 \\
Standard deviation of intercept & 70191.11 & 45122.74 \\
Limit of detection (mg/mL) & 0.0117 & 0.0144 \\
Limit of quantitation (mg/mL) & 0.0355 & 0.0438 \\
Relative standard deviation of retention time (\%) & 1.27 & 1.20 \\
\hline
\end{tabular}


A)

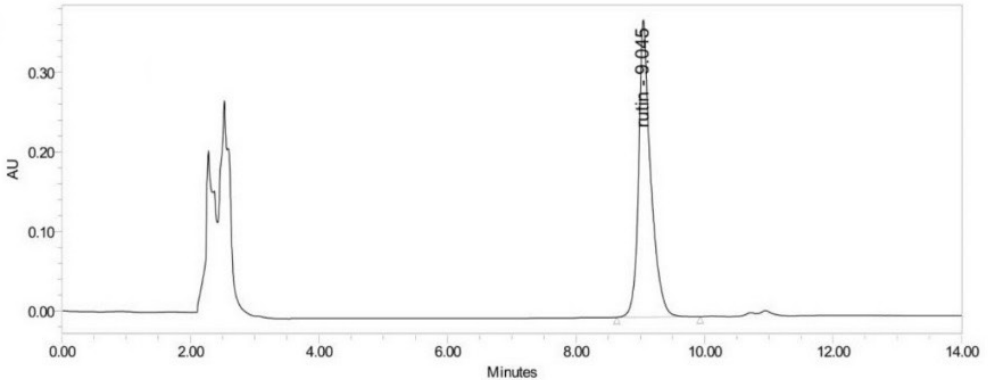

B)

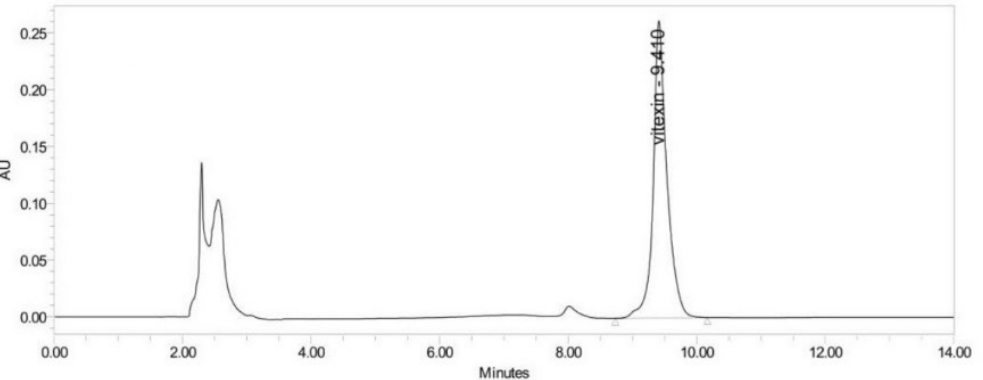

C)

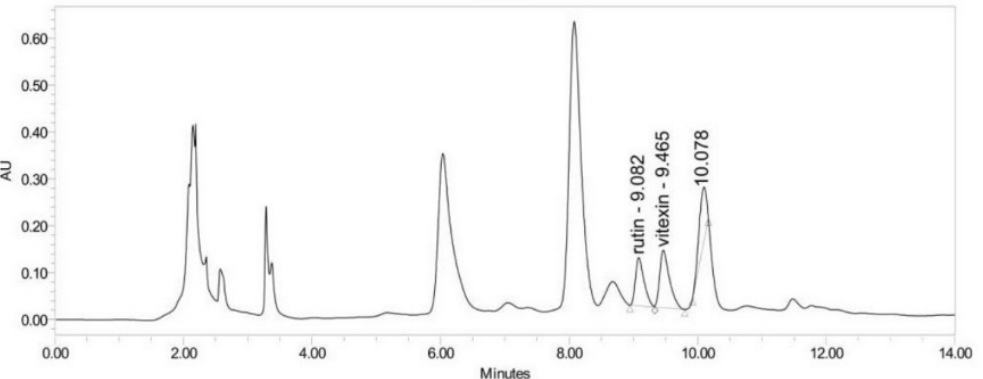

D)



E)

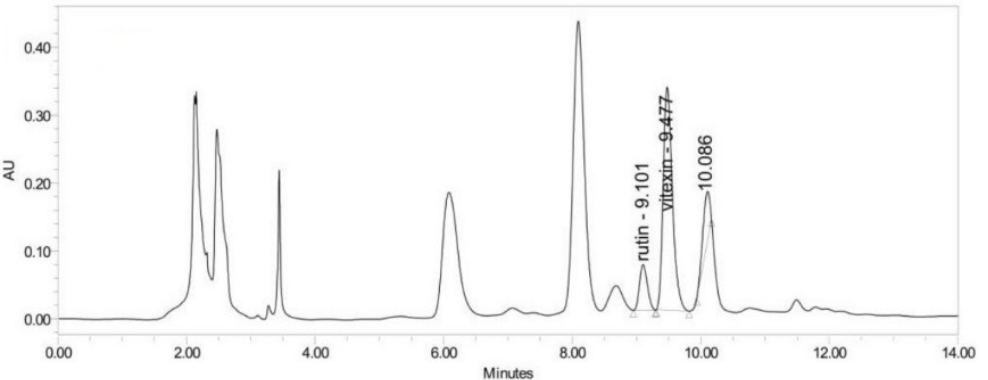

FIGURE 1. UPLC chromatograms of (A) rutin; (B) vitexin; (C) AEPS2;

(D) rutin and AEPS2; and (E) vitexin and AEPS2 
TABLE 5. Blood pressure readings at baseline (day-0), day-14 and day-28 after treatment

\begin{tabular}{lccccccccc}
\hline Group & \multicolumn{3}{c}{ SBP (mmHg) } & \multicolumn{3}{c}{ DBP (mmHg) } & \multicolumn{3}{c}{ MAP (mmHg) } \\
\cline { 2 - 9 } & 0 & 14 & 28 & 0 & 14 & 28 & 0 & 14 & 28 \\
\hline Control & $110.22 \pm$ & $109.22 \pm$ & $103.33 \pm$ & $81.44 \pm$ & $87.17 \pm$ & $77.89 \pm$ & $91.04 \pm$ & $94.52 \pm$ & $86.37 \pm$ \\
& 3.14 & 4.16 & 3.57 & 6.38 & 5.03 & 2.63 & 5.19 & 4.41 & 2.60 \\
AEPS2 & $111.06 \pm$ & $112.5 \pm$ & $100.33 \pm$ & $81.61 \pm$ & $80.0 \pm$ & $78.56 \pm$ & $91.43 \pm$ & $90.83 \pm$ & $85.82 \pm$ \\
& 3.58 & 3.99 & 3.25 & 3.10 & 5.26 & 4.64 & 3.23 & 2.84 & 3.60 \\
Dexamethasone & $103.11 \pm$ & $132.72 \pm$ & $143.06 \pm$ & $76.83 \pm$ & $105.28 \pm$ & $104.61 \pm$ & $85.59 \pm$ & $114.43 \pm$ & $117.43 \pm$ \\
& 4.07 & $3.07^{* *}$ & $3.65^{* *}$ & 4.09 & $2.58^{*}$ & $2.32^{* *}$ & 3.13 & $2.30^{*}$ & $2.06^{* *}$ \\
Dexamethasone & $105.89 \pm$ & $109.28 \pm$ & $105.22 \pm$ & $82.83 \pm$ & $86.56 \pm$ & $82.83 \pm$ & $90.52 \pm$ & $94.13 \pm$ & $90.30 \pm$ \\
+ AEPS2 & 3.55 & $2.95^{\# \#}$ & $2.89^{\# \#}$ & 3.83 & $5.31^{\#}$ & $3.49^{\# \#}$ & 3.37 & $4.41^{\#}$ & $2.53^{\# \#}$ \\
Dexamethasone & $114.56 \pm$ & $111.17 \pm$ & $102.83 \pm$ & $79.56 \pm$ & $89.28 \pm$ & $80.89 \pm$ & $91.22 \pm$ & $96.57 \pm$ & $88.20 \pm$ \\
+ captopril & 4.04 & $3.05^{\# \#}$ & $3.05^{\# \#}$ & 2.98 & $5.65^{\#}$ & $6.11^{\#}$ & 3.05 & $4.52^{\#}$ & $4.97^{\#}$ \\
\hline
\end{tabular}

SBP: systolic blood pressure; DBP: diastolic blood pressure; MAP: mean arterial pressure; AEPS2: aqueous extract of PS2; mmHg: millimeter mercury. Data was expressed as mean \pm SEM, $n=6\left({ }^{*} P<0.05\right.$ compared to control group within the same day, ${ }^{* *} P<0.001$ compared to control group within the same day, ${ }^{\sharp} P<0.05$ compared to dexamethasone group within the same day, ${ }^{\#} P<0.001$ compared to dexamethasone group within the same day)

\section{DISCUSSION}

PS2 was used in this study as its heavy metal and microbial contents were within the safe limits set by the Malaysian National Pharmaceutical Regulatory Agency (NPRA) for traditional medicine (NPRA 2016). PS1 contained higher cadmium and lead compared with PS2 maybe because PS1 was obtained from a location near an old mine and was therefore more prone to heavy metal contamination. PS1 also had total counts of viable aerobic bacteria and fungi that were above the specified limit set. Improper post-harvest handling of plant materials and increase in temperature and humidity in the environment might contribute to excessive microbial growth (Zuza Jnr. et al. 2018).

In this study, the antioxidant activity of AEPS2 based on DPPH radical scavenging assay was $50.00 \pm 2.88 \%$. A previous study showed that the aqueous extract of P. sarmentosum has a high DPPH radical scavenging activity of $96.21 \pm 0.88 \%$ (Zainudin et al. 2015). Antioxidant activity could be affected by several factors, such as the location source and age of plant, post-harvesting process, extraction method, and phytochemical content. PS1 and PS2 leaves were not collected from the same place as the previous study. Both samples might have been subjected to different altitudes, amount of sunlight, and temperature. Altitude and the amount of sunlight received yearly are directly correlated with the flavonoid content and antioxidant activity of a plant. Moreover, temperature is inversely correlated with the phenolic compound in a plant (Liu et al. 2016).

Standards rutin and vitexin were used as chemical markers for the quality determination of $P$. sarmentosum extract using UPLC technique. The UPLC calibration curve analyses of rutin and vitexin and the relative standard deviation of retention time of was less than $2 \%$ indicated that the method is accurate and precise (ICH 2005). The limit of detection and limit of quantitation showed dependable identification and quantification of rutin and vitexin in AEPS2. The system used in this study was modified from a previous study (Ugusman et al. 2012) with the use of a different machine and column to ensure the better separation of the markers.

A previous study reported that the retention times for vitexin and rutin were 15.382 and $17.450 \mathrm{~min}$, respectively (Ugusman et al. 2012). In the present study, we achieved shorter retention times for vitexin (9.465 $\mathrm{min}$ ) and rutin (9.082 $\mathrm{min})$. Retention time can be influenced by the type of stationary phase, sample size, column dimension, mobile phase composition and flow rate, pressure, and temperature (Meyer 2013). Lower temperature produces higher eluent viscosity, which increases retention time. In a reverse-phase system, water is the weakest mobile phase as water cannot interact with a non-polar group. Therefore, a higher amount of water 
in the mobile phase produces slower sample elution rate and leads to longer retention time. Longer column or slower mobile phase can also increase retention time (Meyer 2013).

In this study, $20 \mu \mathrm{g} / \mathrm{kg} / \mathrm{day}$ dexamethasone s.c. induced hypertension in Sprague-Dawley rats as measured on days 14 and 28 of treatment. Another study used $30 \mu \mathrm{g} / \mathrm{kg} /$ day dexamethasone s.c. for 14 days to induce hypertension in rats (Safaeian et al. 2017). One of the mechanisms of dexamethasone-induced hypertension is through increased oxidative stress (Ong et al. 2009). Dexamethasone increases serum malondialdehyde (MDA) and decreases superoxide dismutase (SOD) and catalase (CAT) in rats (Hasona \& Morsi 2018). Previous studies showed that the aqueous extract of $P$. sarmentosum lowers oxidative stress by reducing MDA (Hafizah et al. 2010) and increasing the expression of antioxidant enzymes SOD, CAT, and gluthatione peroxidase in endothelial cells (Ugusman et al. 2011).

Most NO in the blood vessels are produced by endothelial nitric oxide synthase (eNOS). Dexamethasone inhibits eNOS mRNA and protein expression in cultured endothelial cells (Tobias et al. 2015) and reduces eNOS and NO levels in rat plasma (Huyut et al. 2018). The aqueous extract of $P$. sarmentosum reduces blood pressure in SHRs by lowering oxidative stress and increasing NO (Zainudin et al. 2015). The extract enhances endothelial NO production by stimulating eNOS activity (Ugusman et al. 2010). The increase in NO leads to vasodilation and thus reduces blood pressure.

AEPS2 contained flavonoids, such as rutin and vitexin, which have antioxidant and antihypertensive effects. Treatment with rutin lowers blood pressure in renovascular hypertensive rat model (Kaur \& Muthuraman 2016). The aqueous extract of $P$. sarmentosum also contains other flavonoids, such as piperine (Hussain et al. 2009), myricetin, and quercetin (Ghazali et al. 2018). Piperine reduces MAP when given to normotensive rats (Manjusha et al. 2018), and myricetin reduces the SBP of deoxycorticosterone acetate salt-induced hypertensive rats (Borde et al. 2011). In addition, quercetin attenuates hypertension in L-NAME-induced hypertensive rats (Calabro et al. 2018). This study used AEPS2 instead of the isolated active compound from AEPS2; therefore, this study was not able to identify the specific active compound(s) in AEPS2 that gave rise to the antihypertensive effect in dexamethasoneinduced hypertensive rats. However, we suggest that the antihypertensive effect was mediated by the flavonoids mentioned herewith.

\section{CONCLUSION}

The aqueous extract of $P$. sarmentosum leaves quantified for rutin and vitexin using a UPLC method could lower the blood pressure of dexamethasone-induced hypertensive rats. However, future studies are needed to unravel the underlying mechanisms of this antihypertensive effect.

\section{ACKNOWLEDGEMENTS}

The authors wish to thank Universiti Kebangsaan Malaysia Medical Centre for providing the research grant (FF-2019-479).

\section{REFERENCES}

Albrecht, E., Kern, C. \& Kirkham, K.R. 2015. A systematic review and meta-analysis of perineural dexamethasone for peripheral nerve blocks. Anaesthesia 70(1): 71-83.

Amran, A.A., Zakaria, Z., Othman, F., Das, S., Raj, S. \& Nordin, N.A.M.M. 2010. Aqueous extract of P. sarmentosum decreases atherosclerotic lesions in high cholesterolemic experimental rabbits. Lipids in Health and Disease 9(44): $1-6$.

Borde, P., Mohan, M. \& Kasture, S. 2011. Effect of myricetin on deoxycorticosterone acetate (DOCA)-salt-hypertensive rats. Natural Product Research 25(16): 1549-1559.

British Pharmacopeia Commission. 2018. British Pharmacopeia. London: Stationery Office.

Calabro, V., Litterio, M.C., Fraga, C.G., Galleano, M. \& Piotrkowski, B. 2018. Effects of quercetin on heart nitric oxide metabolism in L-NAME treated rats. Archives of Biochemistry and Biophysics 647: 47-53.

Ghazali, N.F., Mohd, M.A., Ibrahim, M.A. \& Muhammad, T.S.T. 2018. Phytochemical and pharmacological profile of kaduk (Piper sarmentosum Roxb.). Malayan Nature Journal 70(2): 195-202.

Hafizah, A.H., Zaiton, Z., Zulkhairi, A., Ilham, A.M., Mohd, M., Nor, N. \& Zaleha, A.M. 2010. P. sarmentosum as an antioxidant on oxidative stress in human umbilical vein endothelial cells induced by hydrogen peroxide. Journal of Zhejiang University 11(5): 357-365.

Hasona, N. \& Morsi, A. 2018. Grape seed extract alleviates dexamethasone-induced hyperlipidemia, lipid peroxidation, and hematological alteration in rats. Indian Journal of Clinical Biochemistry 34(2): 213-218.

Hussain, K., Ismail, Z., Sadikun, A. \& Ibrahim, P. 2009. Antioxidant, anti-TB activities, phenolic and amide contents of standardised extracts of Piper sarmentosum Roxb. Natural Product Research 23(3): 238-249.

Hussain, K., Ismail, Z., Sadikun, A. \& Ibrahim, P. 2010. Standardization and in vivo antioxidant activity of ethanol extracts of fruit and leaf of Piper sarmentosum. Planta Medica 76(5): 418-425.

Huyut, Z., Bakan, N., Yildirim, S. \& Alp, H.H. 2018. Effects of the phosphodiesterase-5 (PDE-5) inhibitors, avanafil and zaprinast, on bone remodeling and oxidative damage in a rat model of glucocorticoid-induced osteoporosis. Medical Science Monitor Basic Research 24: 47-58.

ICH. 2005. Validation of analytical procedures: text and methodology Q2(R1). International Conference on Harmonisation of Technical Requirements for Registration of Pharmaceuticals for Human Use. Switzerland: International Conference on Harmonisation. 
Kaur, S. \& Muthuraman, A. 2016. Therapeutic evaluation of rutin in two-kidney one-clip model of renovascular hypertension in rat. Life Sciences 150: 89-94.

Kumari, R. \& Kotecha, M. 2016. A review on the standardization of herbal medicines. International Journal of Pharma Sciences and Research 7(2): 97-106.

Liu, W., Dongxue, Y., Li, N., Xiaogai, H., Dongmei, W., Li, D. \& Liu, J. 2016. Influence of environmental factors on the active substance production and antioxidant activity in Potentilla fruticosa L. and its quality assessment. Nature 6: 1-18.

Liu, W., Zhao, Z., Na, Y., Meng, C., Wang, J. \& Bai, R. 2018. Dexamethasone-induced production of reactive oxygen species promotes apoptosis via endoplasmic reticulum stress and autophagy in MC3T3-E1 cells. International Journal of Molecular Medicine 41(4): 2028-2036.

Manjusha, R.K., Begum, S., Begum, A. \& Bharathi, K. 2018. Antioxidant potential of piperidine containing compounds-a short review. Asian Journal of Pharmaceutical and Clinical Research 11(8): 66-73.

Meyer, V.R. 2013. Practical High-Performance Liquid Chromatography. Chichester: John Wiley \& Sons.

National Pharmaceutical Regulatory Agency (NPRA), Ministry of Health. 2016. Drug Registration Guidance Document (DRGD). 2nd ed. Selangor: NPRA.

Nik Mohd Alwi, N.A., Zakaria, Z., Karim, A.A.H., Nordin, N.A.M.M. \& Ugusman, A. 2018. Antihypertensive effect of Piper sarmentosum in L-NAME-induced hypertensive rats. Sains Malaysiana 47(10): 2421-2428.

Ong, S., Zhang, Y. \& Whitworth, J. 2009. Mechanisms of dexamethasone-induced hypertension. Current Hypertension Reviews 5(1): 61-74.

Safaeian, L., Baniahmad, B., Esfandiari, Z. \& Alavi, S.A. 2017. Portulaca oleracea seeds extract does not prevent dexamethasone-induced hypertension in rats. Journal of Herbmed Pharmacology 7(1): 8-12.

Seyyedan, A., Yahya, F., Kamarolzaman, M.F.F., Suhaili, Z., Desa, M.N.M., Khairi, H.M., Somchit, M.N., Fatimah, C.A., Teh, L.K., Salleh, M.Z. \& Zakaria, Z.A. 2013. Review on the ethnomedicinal, phytochemical and pharmacological properties of Piper sarmentosum: Scientific justification of its traditional use. Tang (Humanitas Medicine) 3(3): $1-32$.

Shi, Y.N., Liu, F.F., Jacob, M.R., Li, X.C., Zhu, H.T., Wang, D., Cheng, R.R., Yang, C.R., Xu, M. \& Zhang, Y.J. 2017. Antifungal amide alkaloids from the aerial parts of Piper flaviflorum and P. sarmentosum. Planta Medica 83(1): 143-150.

Tobias, S., Habermeier, A., Siuda, D., Reifenberg, G., Xia, N., Closs, E.I., Förstermann, U. \& Li, H. 2015. Dexamethasone, tetrahydrobiopterin and uncoupling of endothelial nitric oxide synthase. Journal of Geriatric Cardiology 12(5): 528-539.

Trindade, N.R., Lopes, P.R., Naves, L.M., Fajemiroye, J.O., Alves, P.H., Amaral, N.O., Liao, L.M., Rebelo, A.C.S., Castro, C.H., Braga, V.A., Menegatti, R. \& Pedrino, G.R. 2018. The newly synthesized pyrazole derivative 5-(1-(3 fluorophenyl)-1H-pyrazol-4-yl)-2H-tetrazole reduces blood pressure of spontaneously hypertensive rats via $\mathrm{NO} /$ cGMO pathway. Frontiers in Physiology 9(1073): 1-10.

Ugusman, A., Zakaria, Z., Hui, C.K. \& Nordin, N.A.M.M 2011. P. sarmentosum inhibits ICAM-1 and Nox4 gene expression in oxidative stress-induced human umbilical vein endothelial cells. BMC Complementary and Alternative Medicine 11(31): 1-8.

Ugusman, A., Zaiton, Z., Hui, C.K., Nordin, N.A.M.M. \& Zaleha, A.M. 2012. Flavonoids of $P$. sarmentosum and its cytoprotective effects against oxidative stress. EXCLI Journal 11: 705-714.

Ugusman, A., Zakaria, Z., Hui, C.K. \& Nordin, N.A.M.M 2010. P. sarmentosum increases nitric oxide production in oxidative stress: A study on human umbilical vein endothelial cells. Clinics 65(7): 709-714.

Vrankova, S., Zemancikova, A., Torok, J. \& Pechanova, O. 2019. Effect of low dose L-NAME pretreatment on nitric oxide/reactive oxygen species balance and vasoactivity in L-NAME/Salt-induced hypertensive rats. Journal of Physiology and Pharmacology 70(4): 535-544.

WHO. 2013. Traditional Medicine Strategy. Alternative and Integrative Medicine. Geneva: WHO Press.

Xiao, H., Wen, Y., Pan, Z., Shangguan, Y., Qin, J., Tan, Y., Jiang, H., Li, B., Zhang, Q., Chen, L. \& Wang, H. 2018. Increased $\mathrm{H} 3 \mathrm{~K} 27 \mathrm{ac}$ level of ACE mediates the intergenerational effect of low peak bone mass induced by prenatal dexamethasone exposure in male offspring rats. Cell Death and Disease 9(638): 1-14.

Zainudin, M.M., Zakaria, Z. \& Nordin, N.A.M.M. 2015. The use of $P$. sarmentosum leaves aqueous extract (Kadukmy ${ }^{\mathrm{TM}}$ ) as antihypertensive agent in spontaneous hypertensive rats. BMC Complementary and Alternative Medicine 15(54): 1-10.

Zuza Jnr., E., Muitia, A., Amane, M.I.V., Brandenburg, R.L., Emmott, A. \& Mondjana, A.M. 2018. Effect of harvesting time and drying methods on aflatoxin contamination in groundnut in Mozambique. Journal of Postharvest Technology 6(2): 90-103.

Muhammad Firdaus Azmi, Amilia Aminuddin, Adila A Hamid \& Azizah Ugusman*

Physiology Department

Faculty of Medicine

Universiti Kebangsaan Malaysia Medical Centre

56000 Kuala Lumpur, Federal Territory

Malaysia

Jamia Azdina Jamal

Drug and Herbal Research Centre

Faculty of Pharmacy

Universiti Kebangsaan Malaysia

50300 Kuala Lumpur, Federal Territory

Malaysia

*Corresponding author; email: dr.azizah@ppukm.ukm.edu.my

Received: 1 January 2020

Accepted: 22 June 2020 